\title{
Integration of Ground Magnetics and Energy Dispersive X-Ray Fluorescence Spectroscopy in Ilmenite Prospection in Magaoni, Kenya
}

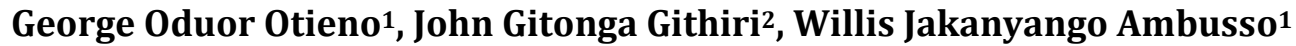 \\ ${ }^{1}$ Kenyatta University, Nairobi, Kenya \\ 2Jomo-Kenyatta University of Agriculture, Science and Technology, Nairobi, Kenya \\ Email: oduorgeorgy@yahoo.com
}

Received 14 January 2016; accepted 19 February 2016; published 22 February 2016

Copyright (C) 2016 by authors and Scientific Research Publishing Inc.

This work is licensed under the Creative Commons Attribution International License (CC BY). http://creativecommons.org/licenses/by/4.0/

(c) (i) Open Access

\section{Abstract}

The geology of Magaoni area is associated with the presence of heavy minerals [1]. Magaoni's neighbours Maumba and Nguluku where ilmenite was discovered by Tiomin Resource Inc. in 1996, using drilling and chemical analysis [2]. Ilmenite mineral is known to be magnetically weak, but provides observable magnetic response [3]. In this study, ground magnetic survey method was carried out to map magnetic anomalies of established stations, associated with ilmenite bearing formations. The magnetic contour map plotted showed weak and shallow magnetic signatures spread throughout the study area. 2D Euler deconvolution solutions revealed presence of magnetised formations from near surface to a maximum depth of about $450 \mathrm{~m}$ at some points. The weak magnetic formations of near surface indicated presence of ilmenite. Energy dispersive X-ray spectroscopy was done on soil samples collected randomly from the study area to determine the percentage of iron and titanium oxides. The results showed elevated values of titanium dioxide, ranging from $1.5 \%$ to $13 \%$ which is way above the global average of about $0.7 \%$ [4]. The percentage of iron oxide was low, ranging from $1.5 \%$ to $4 \%$, this being the reason for weak magnetisation of the study area.

\section{Keywords}

Ilmenite, Magnetic Survey, Euler Deconvolution, Spectroscopy

\section{Introduction}

Mineral potential of Kwale County has been previously studied using methods such as aeromagnetic survey,

How to cite this paper: Otieno, G.O., Githiri, J.G. and Ambusso, W.J. (2016) Integration of Ground Magnetics and Energy Dispersive X-Ray Fluorescence Spectroscopy in Ilmenite Prospection in Magaoni, Kenya. Open Journal of Applied Sciences, 6, 79-88. http://dx.doi.org/10.4236/ojapps.2016.62008 
satellite imaging and Shuttle Radar Topography Mission. The studies revealed the presence of dune-like structure in the north-eastern part of the county and ferrous magnetic elements along the valley in between Kiruku and Mrima. The aeromagnetic data showed that the area is magnetically noisy on the eastern side, indicating shallow source anomalies. Ilmenite is known to be mineral sand that is weakly magnetic [5], in Kenya it was discovered to exist at the coastal region. A major study to delineate ilmenite bearing formations was done in 1996 by Tiomin Company. The exploration was done at the coast specifically in Kwale and substantial deposits were mapped out on the eastern side, a few kilometres from Magaoni. The deposits contained ilmenite as the dominant mineral and also rutile and zircon. Tiomin applied geological and geochemical techniques in their survey [6]. The quantity discovered in Kwale County is economically viable; Base Titanium Company is currently mining and exporting ilmenite and rutile from the deposits. The objective of this study was to determine the lateral extension of ilmenite deposits in Kwale County using ground magnetics.

\subsection{Description of the Study Area}

Magaoni is located about $50 \mathrm{~km}$ south of Mombasa, off Ukunda-Lunga road, the area lies within the coordinates $4^{\circ} 22^{\prime} \mathrm{S} 39^{\circ} 20^{\prime} \mathrm{E}$ and $4^{\circ} 25^{\prime} \mathrm{S} 39^{\circ} 20^{\prime} \mathrm{E}$. The study area is 7 kilometres from where mining of ilmenite is being done (Figure 1).

\subsection{Geology of the Study Area}

Magaoni is found within the Magarini sand grit. The mineralisation of the area is made up of stratified Aeolian sands of the Magarini formation and consists mainly mineral sand deposited in dunes, as shown in Figure 2. The area is poorly stratified and contains a silt fraction varying from $15 \%$ to $30 \%$. The rocks exposed consist of sediments ranging in age from Permo-Carboniferous deposition. The Duruma Sandstone Series, which is in the Kenyan correlative of the Karroo System of South and Central Africa, consists of grits, sandstones and shales that have yielded Permain and Triassic fossils, although it is possible that the series ranges down-wards to Upper Carboniferous and upwards to the Lower Jurassic [1].

The series is divided into three broad lithological units with coarse sandstones and grits at the top and bottom of the succession, and a finer sandstones and shales in the middle. Igneous and pyroclastic are confined to Jombo Hill, an alkaline intrusion, and associated satellite vent agglomerates and dykes [1]. The geology of the Kenyan south coast is a major factor in the occurrence of heavy mineral sands. The heavy mineral sands occur in various parts of the coast in almost similar geological environments. Geochemically, mineral sand deposits contain ilmenite, rutile, zirconium as well as other minerals and trace elements that could be of radioactive nature, such as thorium [6].

\section{Materials and Methods}

The ground magnetic study of Magaoni, covered an area of about $25 \mathrm{Km}^{2}$, and consisted of 20 profiles spaced $250 \mathrm{~m}$ apart. A total of 800 magnetic intensity stations were measured with spacing of $100 \mathrm{~m}$ intervals along each line. Each profile had a total length of $4000 \mathrm{~m}$ and 40 magnetic intensity stations with a bearing normal to the regional structure. The magnetic intensity measurements were recorded using a Fluxgate magnetometer manufactured by Stefan Mayer Instruments. It measures the earth's vertical magnetic intensity component. Stations were established using Garmin GPS receiver (Global Positioning System) device from Garmin International, to give their exact positions on the earth in terms of northing and easting coordinates. A Base Station was also established to monitor and remove diurnal variation [8]. A base station was preoccupied after every two to three hoursand diurnal curve plotted for the base station data, which was used for diurnal corrections [9] [10]. IGRF values were obtained from an online IGRF calculator, based on dates of survey, elevation and geographical location of the station or survey area for geomagnetic correction [4].

The anomaly obtained was used to plot a magnetic contour map and profiles of the survey area using Surfer 11 as displayed in Figure 3.

The magnetic anomaly contour map shows that the whole area has weak and shallow magnetisation; this indicates that the area is covered by sedimentary deposits of magnetically weak minerals or materials [11]. The map also shows that the magnetic materials or minerals covering the area are shallow. The magnetic signatures are more pronounced in North-East, South-East, North-West and South-West of the area. The magnetisation of the area trends in the North-South direction. 


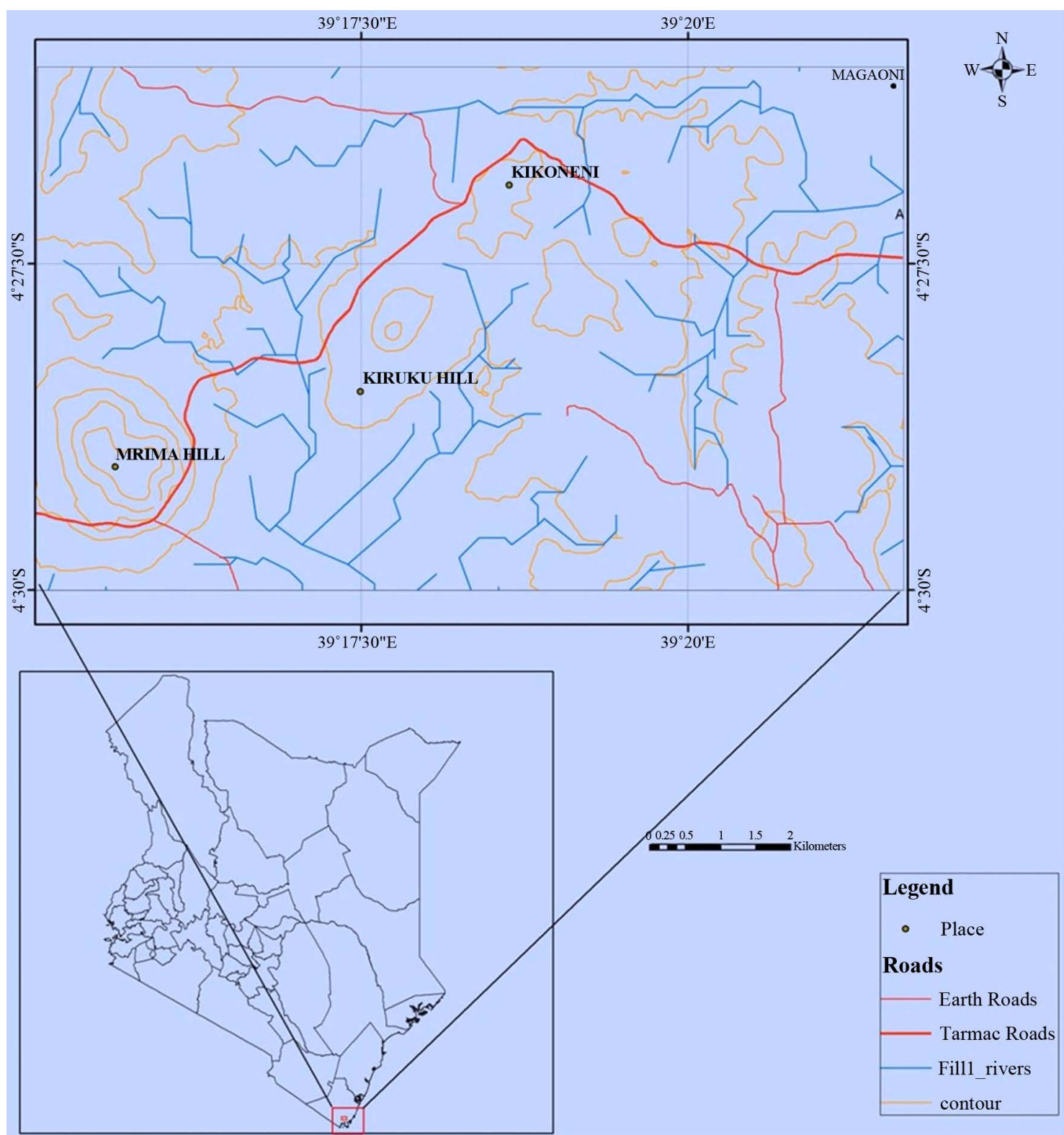

Figure 1. Location map of Magaoni from the map of Kenya [7].

The profiles were drawn to cut across the most anomalous sections of the study area. This was done to enable further analysis such as trend removal, vertical and horizontal derivatives and Euler deconvolution (Figure 4). Trend removal, derivative and Euler deconvolution assist in determining the magnetic field magnitude and depth of the anomaly causative body [12].

\section{Results and Discussion}

\subsection{Interpretation of Contour Maps}

Qualitative interpretation of the magnetic field intensity shows higher magnetic values to the north-east direction running through to the south-west. The probable cause of this high magnetic signature could be due to the presence of iron ores which have high magnetic susceptibility. This is in agreement with the geologic description of the orientation of ferrous deposits in Kwale region. The probable location of ilmenite deposit is characterized by weak magnetic anomaly. 


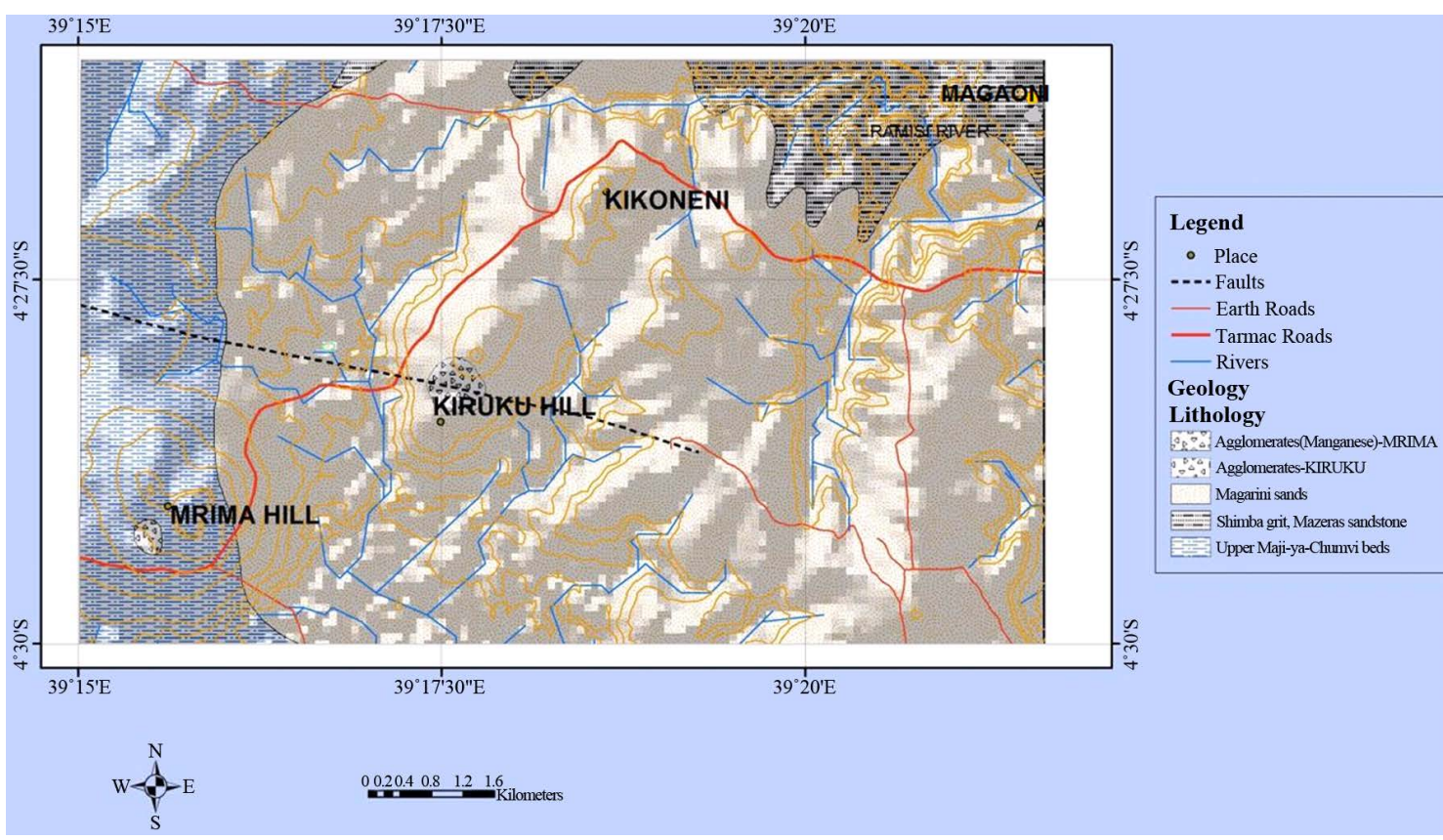

Figure 2. Geological map of Magaoni modified from geological map of Mombasa-Kwale [7].

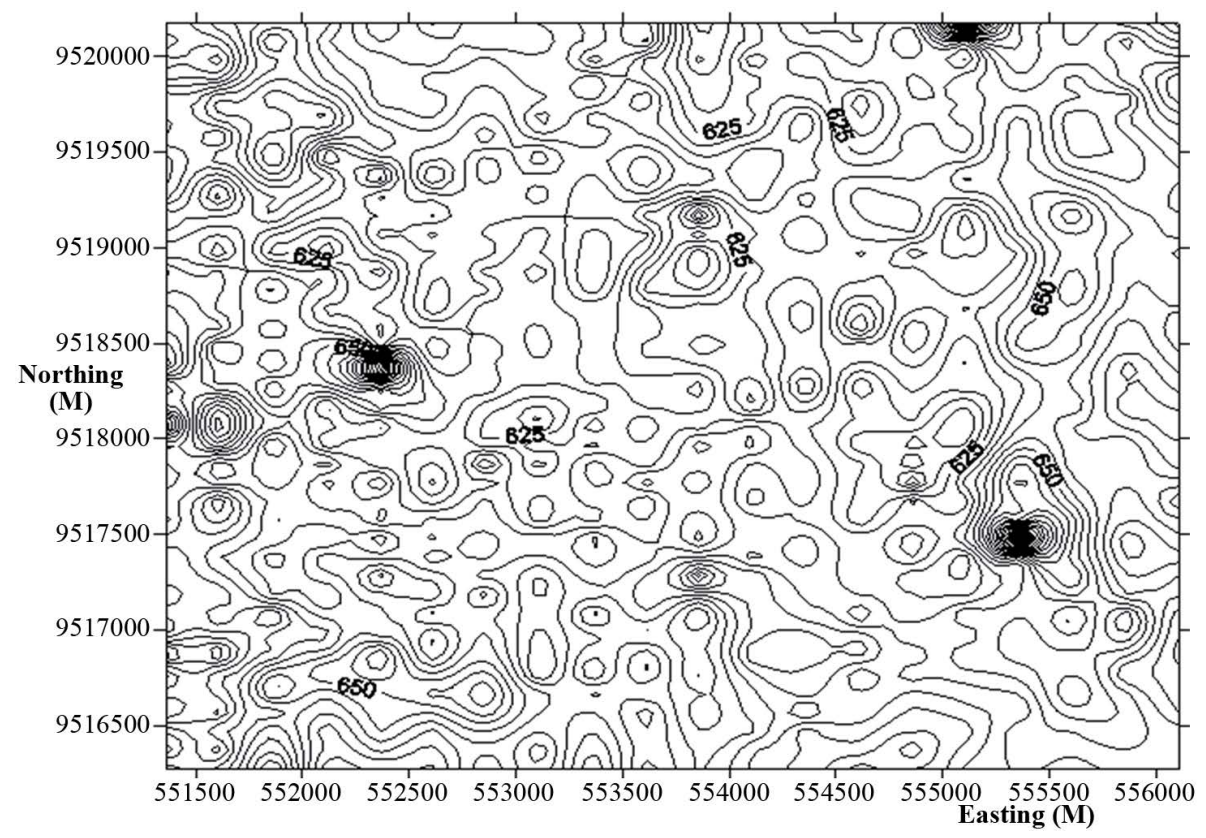

Figure 3. Magnetic anomaly contour map for Magaoni.

The deposits on the northern part of the region and that on the southern part lie on the relatively low magnetic intensity regions, that is, $530 \mathrm{nT}$ and $550 \mathrm{nT}$ respectively.

In the North-West and South-West orientation are regions of low magnetic intensities indicating the presence of ilmenite deposits with the same orientation. Thus, low magnetic intensities in the North-West and South-West orientation as evidenced in the anomaly maps are due to weak magnetic minerals.

\subsection{Euler Deconvolution}

Euler deconvolution is an imaging technique. It gives the vertical and horizontal distribution of the anomaly 


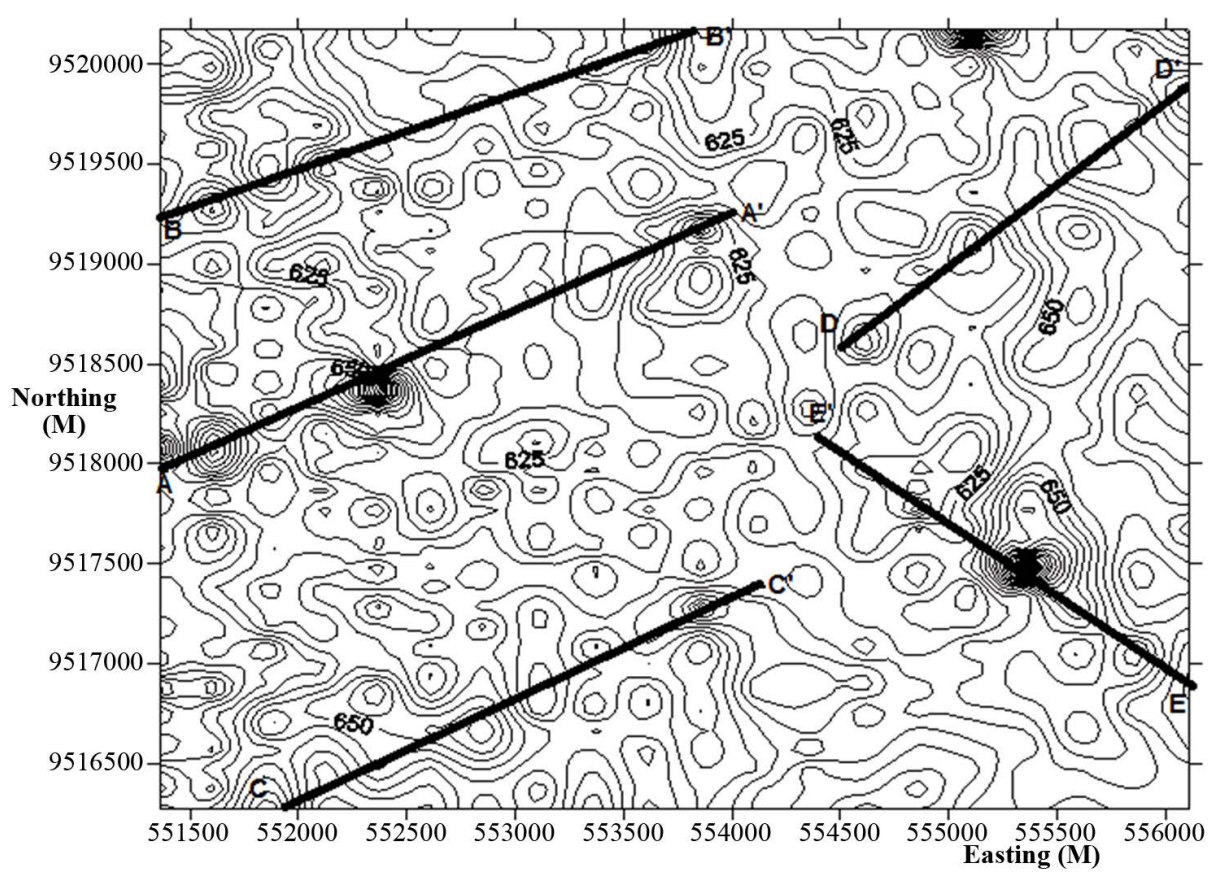

Figure 4. Magnetic anomaly contour map with profiles.

along the profile. Euler deconvolution was done to the data of the five profiles.

\subsection{Interpretation of the Euler Solutions along Profiles}

Along profile AA' (Figure 5), there is a clear indication of ilmenite deposits. The profile shows weak magnetic anomaly which could be the mineral sand layer. The next zone $(550 \mathrm{~m}-650 \mathrm{~m})$ shows no magnetic sources. These signatures are followed to the south by relatively high signatures along the profile and postulated to be magnetic mineral. The entire profile is characterized by small amplitude curves of the anomalies, which shows that shallow source anomalies are present.

There is a strong magnetic anomaly around $(0 \mathrm{~m}-100 \mathrm{~m}),(800 \mathrm{~m}-1200 \mathrm{~m})$ and $(1500 \mathrm{~m}-2400 \mathrm{~m})$ which is an indication of highly magnetic materials near the surface, along profile BB' (Figure 6). The shoulder of the reduction to the pole (RTP) outlines the edge of a possible magnetic structure located at profile distance.

In profile CC' (Figure 7), there is an abrupt change in magnetisation between $900 \mathrm{~m}$ and $1600 \mathrm{~m}$ along the profile. This represents the existence of a magnetically strong source lying between $0 \mathrm{~m}-300 \mathrm{~m}$ depth, and a very low magnetic signature between $0 \mathrm{~m}-900 \mathrm{~m}$ along the profile which could be an indication of a buried pit zone. The discontinuity shown by the solution between $300 \mathrm{~m}$ and $700 \mathrm{~m}$ could be a fault.

Euler solution for profile DD' (Figure 8), the horizontal and vertical gradients highly fluctuate over the entire profile, this indicates change in magnetisation over distance. Sharp and high amplitudes of the anomalies at $1000 \mathrm{~m}$ and $3050 \mathrm{~m}$ along the profile, clearly indicate shallow magnetic structures. Cluster is observed along the entire profile, this shows the presence of magnetic structures on the profile at a depth of between $0 \mathrm{~m}$ and $300 \mathrm{~m}$.

Euler solution for profile EE' shows magnetisation at a depth of about $450 \mathrm{~m}$ from $0 \mathrm{~m}$ to $500 \mathrm{~m}$ along the profile (Figure 9). Between $500 \mathrm{~m}$ and $1000 \mathrm{~m}$, there is a discontinuity which could possibly be a buried it or fault. There is clustering between $1000 \mathrm{~m}$ and $2500 \mathrm{~m}$, indicating presence of shallow magnetic bodies around that region. There is an abrupt change in both horizontal and vertical gradient between $2250 \mathrm{~m}$ and $2750 \mathrm{~m}$, this shows there exists a body of strong magnetisation around that area. Euler solutions portray shallower magnetic deposits within Magaoni.

\section{Energy Dispersive X-Ray Fluorescence Spectroscopy (EDXR-F)}

In this study, Energy Dispersive X-ray Fluorescence Spectrometer was used to analyze for titanium and iron oxides. The equipment used is known as EDX machine. 


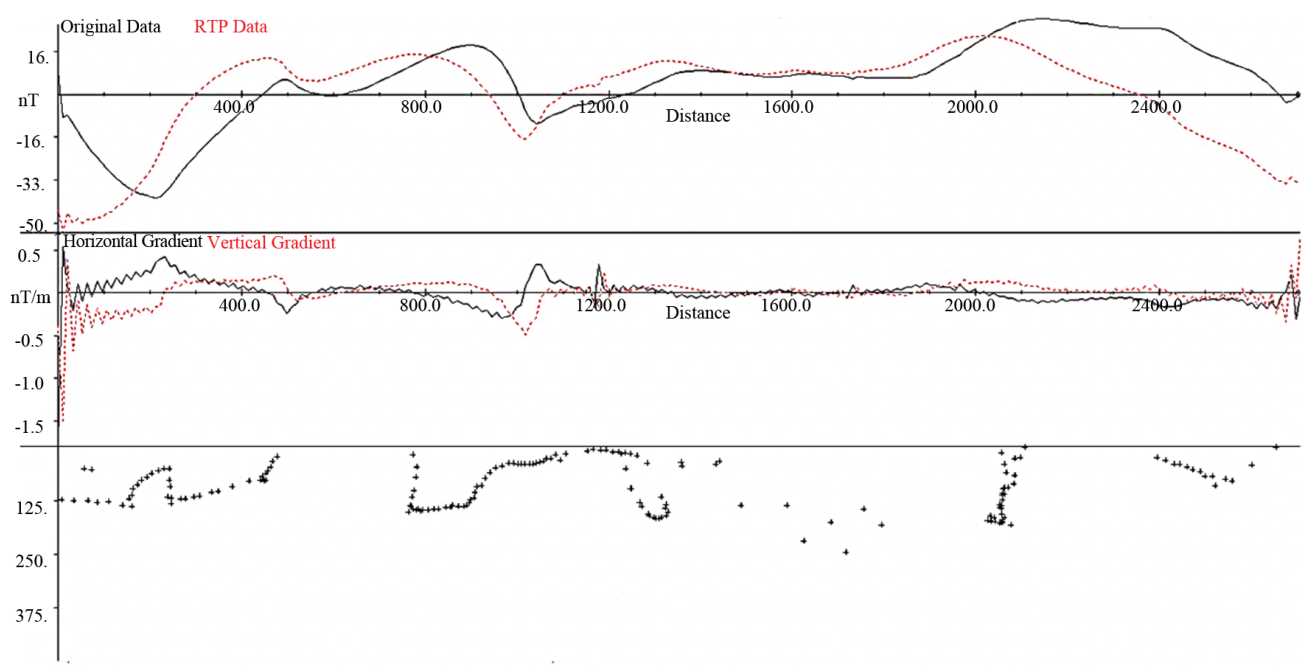

Figure 5. Euler depth solution along magnetic anomaly profile AA'.

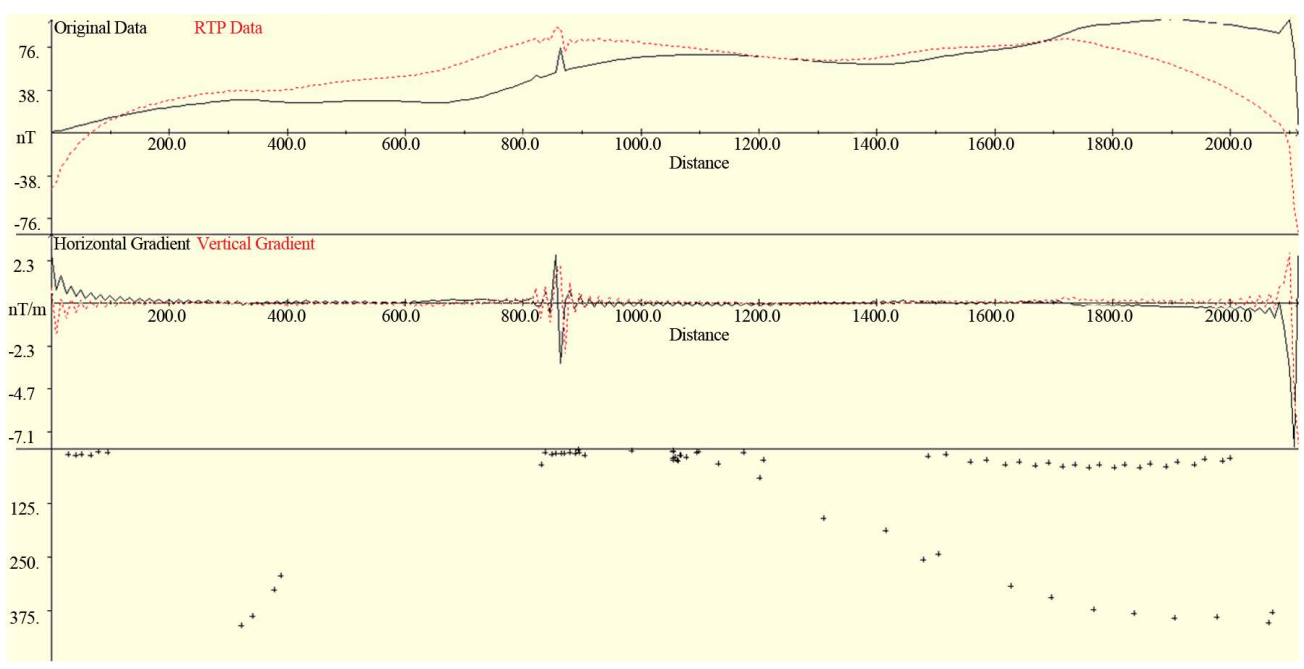

Figure 6. Euler depth solution along magnetic anomaly profile BB'.

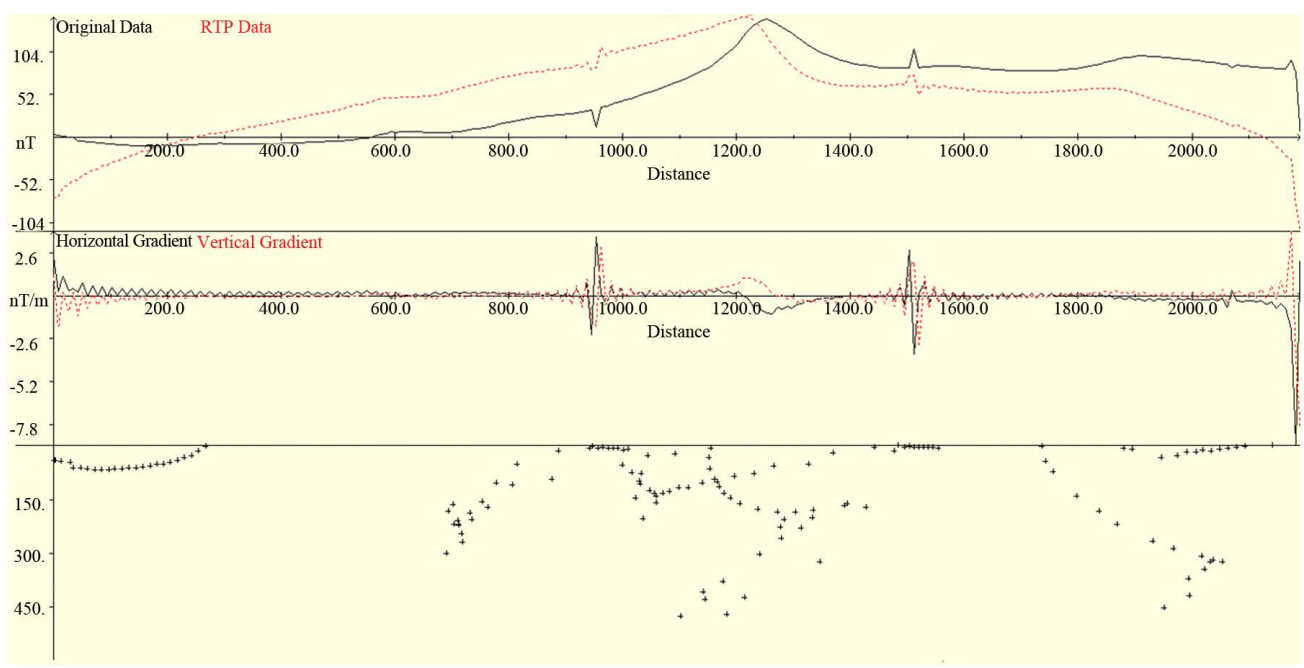

Figure 7. Euler depth solution along magnetic anomaly profile CC'. 


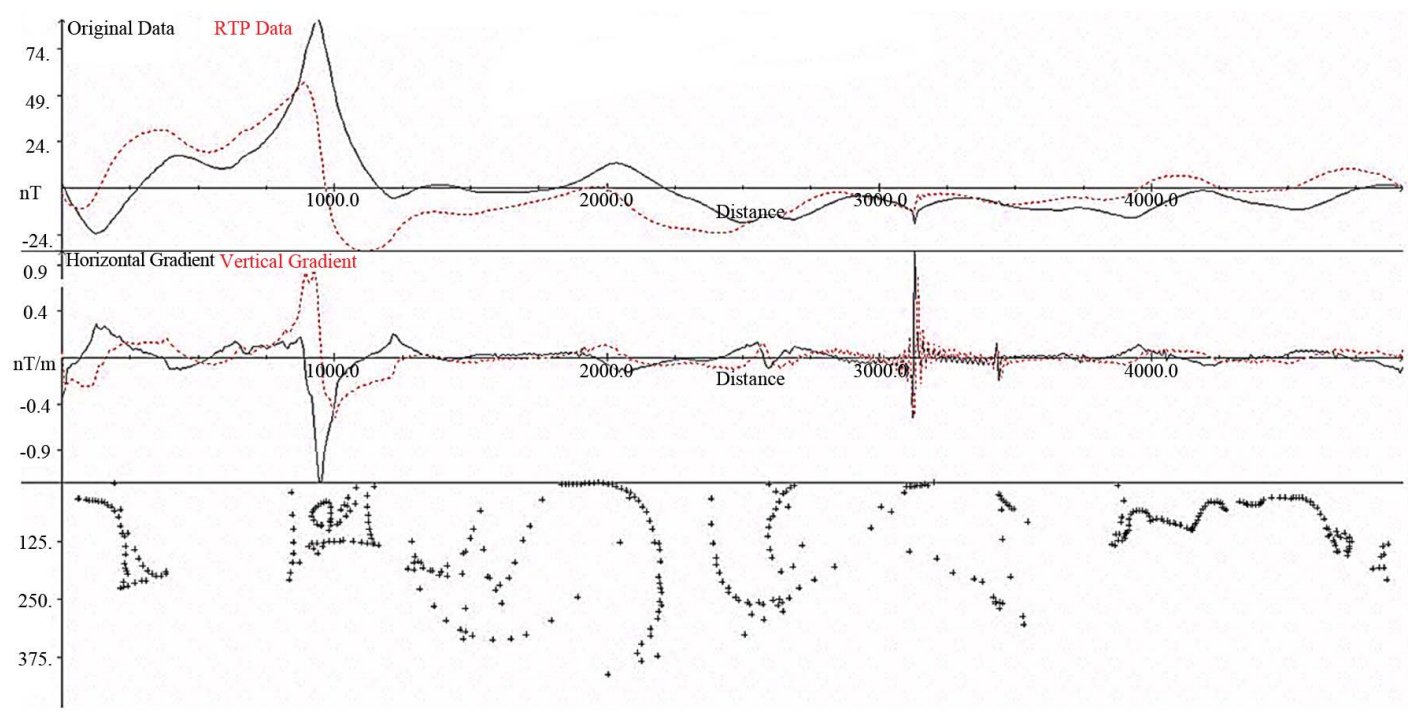

Figure 8. Euler depth solution along magnetic anomaly profile DD’.

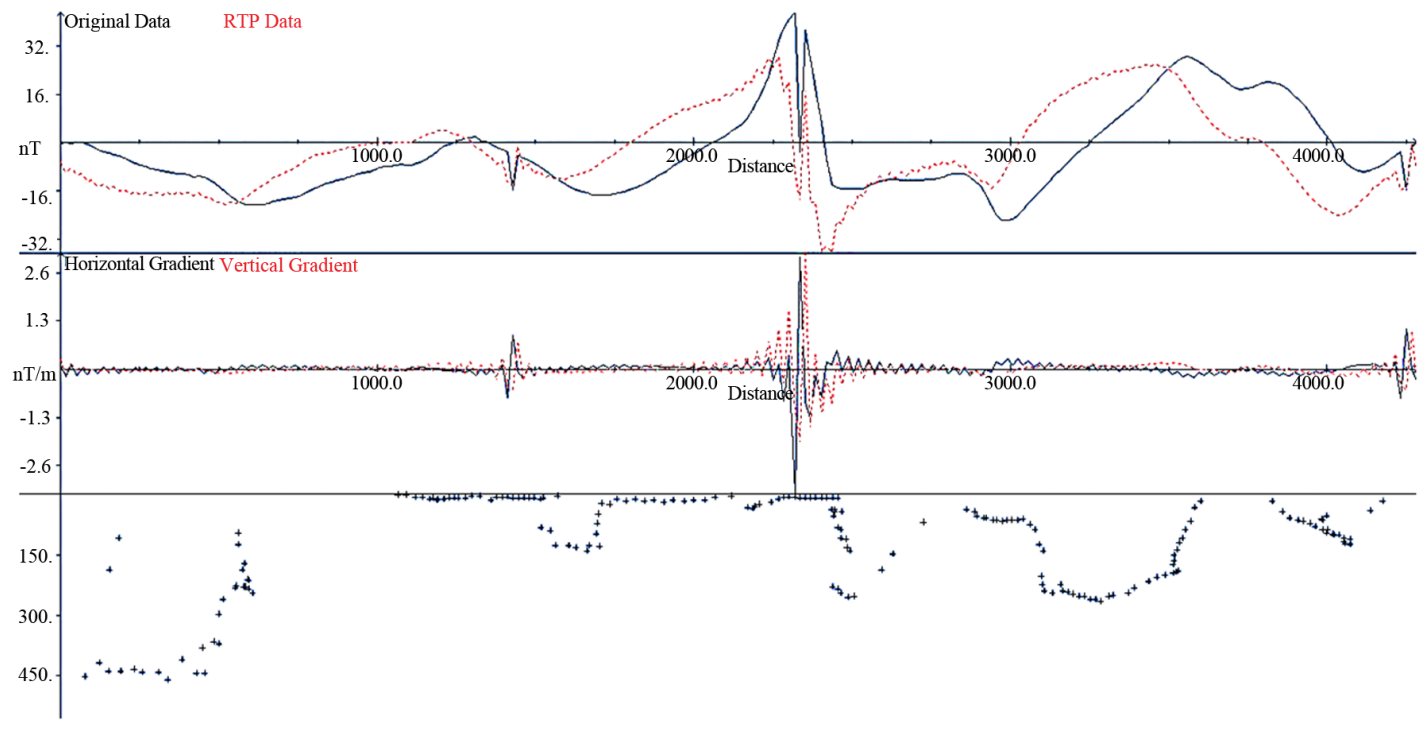

Figure 9. Euler depth solution along magnetic anomaly profile EE'.

\subsection{Spectroscopy Analysis Results}

Sample SS01 was obtained from the surface at station N9516376, E0551360; SS02 was obtained from a depth of $0.5 \mathrm{~m}$ at N9519776, E0551610 and SS03 from a depth of about $1 \mathrm{~m}$ at N9518276, E0553610. The samples were subjected to Energy Dispersive X-ray Fluorescence spectroscopy (EDX-F), to determine for iron and titanium oxides. The type of machine used was EDX800HS2 manufactured by Jiangsu Skyray Instrument Co., Ltd. All the samples showed elevated values of titanium dioxide, values exceeding the global average of about $0.7 \%$ [5] (Tables 1-6). The percentage iron oxide was very low, this is the reason for weak magnetisation of the survey area. There was a good correlation between the values for iron and titanium oxide, indicating the presence of ilmenite. Analysis results are displayed in the tables below.

\subsection{Analysis Results Tables}

\subsubsection{Measurement Conditions for Sample SS01}

Atmosphere: Air. 
Table 1. Equipment settings.

\begin{tabular}{ccccccccc}
\hline Analyte & Target & kV & uA & FI & Acq. (keV) & Anal. (keV) & Time (sec) & DT\% \\
\hline $\mathrm{Ti}-\mathrm{U}$ & $\mathrm{Rh}$ & 50 & 15-Auto & ------- & $0-40$ & $0.0-40.0$ & Live 50 & 24 \\
$\mathrm{Na}-\mathrm{Sc}$ & $\mathrm{Rh}$ & 15 & 689-Auto & ------ & $0-20$ & $0.0-4.4$ & Live 49 & 25 \\
\hline
\end{tabular}

Table 2. Quantitative result for sample SS01.

\begin{tabular}{|c|c|c|c|c|c|}
\hline Analyte & Result & Std. Dev. & Proc.-Calc. & Line & Int. $(\mathbf{c p s} / \mathbf{u A})$ \\
\hline $\mathrm{SiO}_{2}$ & $92.146 \%$ & 0.920 & Quan-FP & $\operatorname{SiK} \alpha$ & 0.4307 \\
\hline $\mathrm{TiO}_{2}$ & $4.411 \%$ & 0.106 & Quan-FP & $\operatorname{TiK} \alpha$ & 2.9330 \\
\hline $\mathrm{Fe}_{2} \mathrm{O}_{3}$ & $1.740 \%$ & 0.032 & Quan-FP & $\mathrm{FeK} \alpha$ & 4.6302 \\
\hline $\mathrm{SO}_{3}$ & $1.255 \%$ & 0.077 & Quan-FP & $\mathrm{S} \mathrm{K} \alpha$ & 0.0295 \\
\hline $\mathrm{ZrO}_{2}$ & $0.448 \%$ & 0.005 & Quan-FP & $\mathrm{ZrK} \alpha$ & 13.4179 \\
\hline
\end{tabular}

Table 3. Equipment settings.

\begin{tabular}{ccccccccc}
\hline Analyte & Target & kV & uA & FI & Acq. (keV) & Anal. (keV) & Time (sec) & DT\% \\
\hline $\mathrm{Ti}-\mathrm{U}$ & $\mathrm{Rh}$ & 50 & 14-Auto & ------- & $0-40$ & $0.0-40.0$ & Live 49 & 26 \\
$\mathrm{Na}-\mathrm{Sc}$ & $\mathrm{Rh}$ & 15 & 446-Auto & ------ & $0-20$ & $0.0-4.4$ & Live 50 & 26 \\
\hline
\end{tabular}

Table 4. Quantitative results for sample SS02.

\begin{tabular}{cccccc}
\hline Analyte & Result & Std. Dev. & Proc.-Calc. & Line & Int. (cps/uA) \\
\hline $\mathrm{SiO}_{2}$ & $79.852 \%$ & 0.610 & Quan-FP & $\mathrm{SiK} \alpha$ & 0.7875 \\
$\mathrm{TiO}_{2}$ & $13.357 \%$ & 0.113 & Quan-FP & $\mathrm{TiK} \alpha$ & 19.8165 \\
$\mathrm{Fe}_{2} \mathrm{O}_{3}$ & $4.338 \%$ & 0.037 & Quan-FP & $\mathrm{FeK} \alpha$ & 20.9211 \\
$\mathrm{ZrO}_{2}$ & $1.712 \%$ & 0.008 & Quan-FP & $\mathrm{ZrK} \alpha$ & 80.6791 \\
$\mathrm{SO}_{3}$ & $0.648 \%$ & 0.045 & Quan-FP & $\mathrm{S} \mathrm{K} \alpha$ & 0.0354 \\
$\mathrm{MoO}_{3}$ & $0.093 \%$ & 0.004 & Quan-FP & $\mathrm{MoK} \alpha$ & 4.3596 \\
\hline
\end{tabular}

Table 5. Equipment settings.

\begin{tabular}{rcccccccc}
\hline Analyte & Target & $\mathbf{k V}$ & $\mathbf{u A}$ & FI & Acq. (keV) & Anal. (keV) & Time (sec) & DT\% \\
\hline $\mathrm{Ti}-\mathrm{U}$ & $\mathrm{Rh}$ & 50 & 15-Auto & ------- & $0-40$ & $0.0-40.0$ & Live 50 & 24 \\
$\mathrm{Na}-\mathrm{Sc}$ & $\mathrm{Rh}$ & 15 & 506-Auto & ------- & $0-20$ & $0.0-4.4$ & Live 50 \\
\hline
\end{tabular}

Table 6. Quantitative result for sample SS03.

\begin{tabular}{|c|c|c|c|c|c|}
\hline Analyte & Result & Std. Dev. & Proc.-Calc. & Line & Int. (cps/uA) \\
\hline $\mathrm{SiO}_{2}$ & $82.871 \%$ & 0.582 & Quan-FP & $\operatorname{SiK} \alpha$ & 0.8236 \\
\hline $\mathrm{Al}_{2} \mathrm{O}_{3}$ & $10.247 \%$ & 0.575 & Quan-FP & $\mathrm{AlK} \alpha$ & 0.0234 \\
\hline $\mathrm{TiO}_{2}$ & $2.8985 \%$ & 0.054 & Quan-FP & $\operatorname{TiK} \alpha$ & 4.7155 \\
\hline $\mathrm{Fe}_{2} \mathrm{O}_{3}$ & $2.151 \%$ & 0.022 & Quan-FP & $\mathrm{FeK} \alpha$ & 14.3774 \\
\hline $\mathrm{SO}_{3}$ & $1.253 \%$ & 0.047 & Quan-FP & $\mathrm{S} \mathrm{K} \alpha$ & 0.0713 \\
\hline $\mathrm{ZrO}_{2}$ & $0.329 \%$ & 0.003 & Quan-FP & $\mathrm{ZrK} \alpha$ & 24.3511 \\
\hline $\mathrm{MnO}$ & $0.186 \%$ & 0.010 & Quan-FP & $\operatorname{MnK} \alpha$ & 1.0144 \\
\hline $\mathrm{V}_{2} \mathrm{O}_{5}$ & $0.065 \%$ & 0.023 & Quan-FP & $\mathrm{V} \mathrm{K} \alpha$ & 0.1462 \\
\hline
\end{tabular}


Table 7. Chemical analyses result for soil samples studied using XRF from Ocean Drilling Program, US [13].

\begin{tabular}{cccccccccc}
\hline Core, Section interval (cm) & Depth (mbsl) & $\mathbf{S i O}_{2}$ & $\mathbf{T i O}_{2}$ & $\mathbf{A l}_{2} \mathbf{O}_{3}$ & $\mathbf{F e}_{2} \mathbf{O}_{3}$ & $\mathbf{M n O}$ & $\mathbf{M g O}$ & $\mathbf{C a O}$ & $\mathbf{N a}_{2} \mathbf{O}$ \\
\hline 115-706C-4R-3, 10-13 & 66.70 & 48.04 & 3.17 & 13.67 & 15.65 & 0.20 & 5.65 & 10.35 & 2.61 \\
115-707C-25R-1, 39-43 & 404.90 & 49.60 & 1.38 & 14.90 & 13.49 & 0.16 & 7.10 & 11.99 & 2.15 \\
115-707C-25R-3, 44-47 & 407.80 & 49.70 & 1.45 & 15.10 & 13.32 & 0.17 & 7.15 & 11.24 & 2.23 \\
115-713A-15R-4, 7-13 & 131.90 & 49.36 & 1.31 & 14.13 & 13.27 & 0.19 & 8.58 & 11.32 & 2.18 \\
115-713A-15R-41, 43-146 & 132.63 & 49.07 & 1.52 & 13.58 & 14.71 & 0.25 & 5.64 & 12.11 & 2.29 \\
115-715A-25-6, 38-42 & 237.00 & 47.93 & 0.98 & 14.98 & 11.82 & 0.18 & 10.97 & 11.64 & 1.58 \\
\hline
\end{tabular}

Collimator: $10 \mathrm{~mm}$.

Spin: Off.

\subsubsection{Measurement Condition for Sample SS02}

Atmosphere: Air.

Collimator: $10 \mathrm{~mm}$.

Spin: Off.

\subsubsection{Measurement Condition for Sample SS03}

Atmosphere: Air.

Collimator: $10 \mathrm{~mm}$.

Spin: Off.

\subsection{Related Work on Quantitative Analysis}

Results in Table 7 show that the percentage oxide of titanium ranges between $0.98 \%$ to $3.17 \%$ and iron oxide between $11.82 \%$ and $15.65 \%$. From global studies, the results indicate presence of ilmenite in the samples and by extension the study area, this was realized when another study was done on the same samples to determine for ilmenite as a mineral, the results were positive especially for samples 706 and $713 \mathrm{~A}$, with $3.17 \%$ and $1.52 \%$ $\mathrm{TO}_{2}$ respectively [4] [5]. Samples from Magaoni gave good results, with percentage $\mathrm{TO}_{2}$ ranging from $2.89 \%$ to $13.35 \%$.

\section{Conclusion}

The Euler solutions and quantitative results of the spectroscopic analysis of soil samples revealed that Magaoni area as a whole is generally characterized by weak magnetic anomaly, presence of titanium oxides in large quantities and low values of iron oxides. The average depth for the near surface magnetic anomaly is $40 \mathrm{~m}$, while that of the deepest is about $500 \mathrm{~m}$. The magnetic signatures are more pronounced in the North-East and South-East of Magaoni. All data give clear indication of the presence of mineral sand containing iron and titanium oxides, which could simply be ilmenite.

\section{Acknowledgements}

Much thanks to the entire physics department of Kenyatta University and Donata Nanyukia for the great support during research and writing of this paper.

\section{References}

[1] Horkel, A.D. (1984) Note on the Geology and Mineral Resources of Southern Kenyan Coast. Mining Journal, 328, 484

[2] McEnroe, S.A. and Brown, L.L. (2000) A Closer Look at Remanence-Dominated Anomalies; Rock-Magnetic Properties and Magnetic Mineralogy. New York Journal of Geophysical Research, 105, 16-20.

[3] McEnroe, S.A., Robinson, P. and Panish, P.T. (1996) Rock-Magnetic Properties, Oxides Mineralogy and Mineral Chemistry in to Aeromagnetic Interpretation and Search for Ilmenite Reserves. Norway Geophysical Survey Report, 96, 
148-152.

[4] McEnroe, S.A. (1997) Ilmenite Mineral Magnetism; Implications for Geophysical Exploration for Ilmenite Deposits. Norway Geological Survey, 433, 36-37.

[5] Wright, P.M. (1981) Gravity and Magnetic Methods in Mineral Exploration. In: Skinner, B.J., Ed., Economic Geology, 75th Anniversary Volume, Economic Geology Publishing Company, New Haven, Connecticut, 829-839.

[6] Caswell, P.V. (1953) Geology of the Mombasa-Kwale Area, Geological Survey of Kenya.

[7] Baker, B.H. (1953) The Alkaline Igneous Complex at Jombo, Geological Survey of Kenya.

[8] Dobrin, M. (1974) Introduction to Geophysical Prospecting. McGraw-Hill, Inc., USA, 630 p.

[9] Hoover, D.B., Heran, W.D., and Hill, P.L., Eds. (1992) The Geophysical Expression of Selected Mineral Deposit Models. U.S. Geological Survey Open-File Report 92-557, 129 p.

[10] Blakely, R.J. (1996) Potential Theory in Gravity and Magnetic Applications. Cambridge University Press, Cambridge.

[11] Merrill, T., McEthinny, M.W. and McFadden, P.L. (1996) The Magnetic Field of the Earth: Paleomagnetism, the Core and the Deep Mantle. Academic Press, San Diego, 531 p.

[12] Jessop, J.A., Hauser, K.L. and Gese, D.D. (1995) Evaluation of Geophysical Methods for Locating Subsurface Hazards in the Shawnee National Forest. DoI Conference on the Environment and Safety, Colorado Springs, CO, April 24-28 1995, 26.

[13] Houseden, et al. (1988) Chemical Analysis of Soil Using X-Ray Fluorescence Spectroscopy, Ocean Drilling Program. 